UDC 378.011.3-051:57(477)

DOI: $10.31470 / 2415-3729-2018-8-123-136$

\title{
Teacher Training as a Prerequisite for the Development of the School Biological Education System in Ukraine
}

\section{Nina Novykova}

Doctor of Philosophy in Pedagogy (Ph.D), Associate Professor, Head of the Department of Natural and Mathematical Education, Municipal Institution of Lviv Regional Council «Lviv Regional Institute of Postgraduate Pedagogical Education» $\triangle$ 18a, Ohiienka Str., Lviv, Ukraine, 79007 E-mail:nninov@ukr.net; novykovanina@gmail.com ORCID: 0000-0002-4284-2332

\section{Підготовка вчителя як необхідна умова розвитку системи шкільної біологічної освіти в Україні}

\section{Ніна Іванівна Новикова}

кандидат педагогічних наук, доцент, завідувач кафедри природничо-математичної освіти Комунальний заклад Львівської обласної ради «Львівський обласний інститут післядипломної педагогічної освіти», $\checkmark$ вул. Огієнка, 18а, м. Львів, Україна, 79007

Дата надходження статті: 02 серпня 2018 р. Стаття прийнята до друку: 25 листопада 2018 р.

\section{Abstract}

The article considers the school biological education as an integral pedagogical system with a certain structure. The purpose of the study is to outline the priority trends in training and advanced training of a biology teacher as an important active person in the system of school biological education for each period of its development. The 
benefit of this study is that the main trends in teacher training as an essential element of the school biological education system, which has its own history, determined by socio-political, economic, cultural factors of the social environment in accordance with the designated periodization of the school biological education system in Ukraine during the XX - early XXI centuries (4 periods), are analyzed. It is determined that the gnostic-professional component provides for the selection and implementation of progressive pedagogical experience as a scientific and methodological condition for the functioning of the system. The directions of increasing the efficiency of methodical work are determined.

The author of the article has made a conclusion that the process of education transformation needs to improve the organizational, methodological, informational and scientific activities of methodological services through: improving the organizational support for the process of identifying objects of experience; forming the scientific and methodological competence of employees involved in this work and providing guidance to this process. In the author's opinion, training a teacher for pedagogical creativity as an integral system is based on a combination of dialectical categories, they are: general (a component of the professional general pedagogical work of a teacher); special (a specificity, which is conditioned by the laws of the creative process and the formation of the creative personality) and individual (it reflects the dependence of training on the personal qualities of a teacher). The author also notes that quality, efficiency, choice and equal access to education as unified priorities of Ukrainian educational policy require constant attention to the systematic training of teachers with new professional qualities. The final line in the article is that the teacher's self-education activity will remain relevant as a necessary factor for the development of Ukrainian national education.

Key words: teacher training, development, school biological education system, structure, trends.

\section{References}

1. Demkov, M. (1910). Pedagogika, ee sovremennoe polozhenie i predstoyaschie zadachi [Pedagogy, its current position and the tasks ahead]. Zhurnal Ministerstva narodnogo prosvescheniya - Journal of the Ministry of Education, 1, 81-102 [in Russian]. 
2. Keyran, L. F. (1978). Struktura metodiki obucheniya kak nauki: na osnove analiza metodik obucheniya biologii [The structure of teaching methods as a science: based on the analysis of methods of teaching biology]. Moskva : Pedagogika [in Russian].

3. Liubar, O. O., Stelmakhovych, M. H., Fedorenko, D. T. (2003). Istoriia ukrainskoi pedahohiky [History of Ukrainian Pedagogy]. Kyiv : Znannia [in Ukraine].

4. Narodna osvita i pedahohichna dumka v Ukrainskii RSR (1917-1967) (1967) [Popular education and pedagogical thought in the Ukrainian SSR (1917-1967)]. Kyiv : Rad. shkola [in Ukraine].

5. Hrynevych, L. et al, (2016). Nova ukrainska shkola: Kontseptualni zasady reformuvannia serednoi shkoly [New Ukrainian School: Conceptual Principles for Reforming the Secondary School] (Ukhvalena rishenniam kolehii MON 27.10.2016 r.). Retrieved from http://mon.gov.ua/\%D0\%9D $\%$ D0\%BE $\%$ D0\%B2\%D0\%B8\%D0\%BD $\%$ D0\%B8\%202016/12/05/konczepcziya.pdf.

6. Pro provedennia komsomolskoho pryiomu molodi do pedahohichnykh instytutiv Ukrainy v 1963 rotsi: Vytiah z protoku zasidannia sekretariatu TsK LKSMU vid 4 liutoho 1963 roku [About the Komsomol reception of young people to the pedagogical institutes of Ukraine in 1963: Extract from the report of the meeting of the Secretariat of the Central Committee of the LCUU of February 4, 1963]. Derzhavnyi arkhiv Lvivskoi oblasti - State Archives of the Lviv region. F. R-163. Op. 4. Spr. 939. Ark. 1-30.

7. Tematyka dlia metodychnykh obiednan i predmetnykh metodychnykh komisii Instruktsii i metodychni vkazivky za 1940 rik (1940) [Topics for methodological associations and subject methodical commissions. Instructions and guidelines for 1940]. Derzhavnyi arkhiv Lvivskoi oblasti - State Archives of the Lviv region. F. R-163. Op. 1. Od. zb. 139. Ark. 18-20.

8. Stuparyk, B. M. (1998). Natsionalna shkola: vytoky, stanovlennia [National School: Origins, Formation]. Kyiv : IZMN.

\section{Вступ}

Ми розглядаємо біологічну освіту в школах України як систему педагогічних явищ із багатьма компонентами і складними 
функціональними взаємозв'язками, що здійснюють взаємний вплив на розвиток певного суспільного середовища. Вивчення шкільної біологічної освіти як цілісної педагогічної системи передбачає певну структуру, що містить п’ять компонентів: 1) цільовий (реалізується через завдання i детермінується суспільними вимогами); 2) змістовий (включає знаннєвий аспект навчальної діяльності як характеристику системи); 3) процесуальний (засоби засвоєння учнями навчальної інформації - організаційні форми навчання, методи, прийоми роботи 3 учнями); 4) гностичнопрофесійний (відбір і впровадження прогресивного педагогічного досвіду як науково-методичної умови функціонування системи); 5) аналітико-результативний (аналіз і оцінка результатів навчально-виховного процесу на певному етапі розвитку системи 3 метою їх коригування).

У дослідженні Л. Кейрана зазначено, що в загальній методиці навчання біології склалась визначена структура, яка містить десять структурних елементів: 1) методика навчання біології - педагогічна наука, 2) історія розвитку основних проблем методики біології, 3) роль біології, 4) виховання в процесі навчання біології, 5) зміст і особливості шкільної біології, 6) розвиток біологічних понять, 7) методика навчання, 8) система форм навчання, 9) матеріальна база навчання та 10) особистість учителя (Кейран, 1978:21).

Кількість структурних елементів методики та їх зміст не $\epsilon$ постійними: вони змінюються і вдосконалюються під впливом потреб суспільного розвитку та досягнень науки, які зі шкільною практикою обумовили розвиток часткових методик навчання окремих предметів і розділів (природознавства; ботаніки; зоології; анатомії, фізіології і гігієни людини; загальної біології). Посібники 3 теоретичним обгрунтуванням досвіду роботи шкіл створювали певну структуру часткових методик, що виникли після Жовтневої революції. У часткових методиках навчання окремим курсам біології розрізняють дві структури: а) основні питання методики навчання курсу 3 такими елементами - навчально-виховне значення курсу, зміст, розвиток понять у процесі навчання, методи навчання, форми навчання й обладнання, особа вчителя; б) методику навчання окремим темам і урокам (Кейран, 1978:62). 
Актуальними для нашого дослідження $є$ історіографічні праці 3 питань розвитку національної системи освіти і педагогічної думки в Україні вітчизняних учених i педагогів (Л. Березівська, І. Білодід, Я. Болюбаш, Я. Бурлака, С. Бухало, Г. Васькович, О. Вознюк, М. Гриценко, М. Грищенко, Н. Гупан, Л. Гуцал, М. Свтух, Н. Калениченко, В. Кремень, В. Курило, О. Любар, Ю. Павленко, Л. Пироженко, Ю. Руденко, Т. Собченко, Б. Ступарик, О. Сухомлинська, М. Ярмаченко).

Теорія і практика системного вивчення шкільного курсу біології розкрита в наукових працях І. Бєлова, Л. Ващенко, В. Курсон, К. Ситника, В. Соболя, М. Тураш, де зазначено роль особи вчителя в реалізації завдань природничої освіти.

Актуальну проблему підготовки педагогічних кадрів як необхідну умову розвитку шкільної освіти вивчали О. Біда, В. Бобрицька, В. Бровдій, В. Галузинський, О. Гірний, I. Дичківська, I. Жерносек, I. Зязюн, В. Луговий, О. Пєхота, С. Сисоєва.

Важливою складовою реалізації завдань шкільного курсу біології $\epsilon$ професійний розвиток учителів, формування їх професійної майстерності, що знайшло відображення в наукових працях українських дослідників: В. Гриньової, Н. Гупана, Г. Данилової, І. Зязюна, М. Свтуха, І. Мороза, Н. Ничкало, О. Савченко, С. Сисоєвої та інших.

Ряд наукових праць присвячено підготовці педагогів до інноваційної діяльності (К. Баханов, І. Бех, Д. Біда, I. Підласий, О. Пометун і Л. Пироженко). Питання підвищення кваліфікації вчителів у закладах післядипломної педагогічної освіти досліджено Г. Даниловою, С. Крисюком, Н. Новиковою, П. Худоминським, О. Шиян та іншими.

У Концепції «Нова українська школа» (2016) визначено новітні орієнтири в реформуванні системи освіти України та роль вчителів природничих дисциплін у забезпеченні формування в учнів компетентностей у природничих науках i технологіях, в уміння вчитися впродовж життя та здатності на власному прикладі заохочувати школярів до самоосвітньої діяльності (Нова українська школа..., 2016). 
Якість, ефективність, вибір i рівний доступ до освіти як уніфіковані пріоритети української освітньої політики вимагають постійної уваги до системної підготовки вчителя 3 новими професійними якостями.

Метою статті є окреслення пріоритетних тенденції у підготовці та підвищенні кваліфікації вчителя біології як важливої дієвої особи в системі шкільної біологічної освіти для кожного періоду іiі розвитку.

\section{Матеріал і методи дослідження}

Використано науково-педагогічні дослідження 3 питань розвитку творчого потенціалу вчителя, ряд архівних матеріалів щодо історії становлення педагогічної майстерності вчителя; застосовано методи аналізу - історіографічний, порівняльний, ретроспективний, що уможливили порівняти тенденції розвитку досліджуваного феномену на окремих етапах; пошуковобібліографічний метод дав змогу виокремити і вивчити бібліотечні i бібліографічні видання; проаналізувати історико-педагогічну та науково-методичну літературу розвитку системи шкільної біологічної освіти в Україні.

\section{Результати та їх обговорення}

Нами виділено чотири основні періоди і відповідні етапи формування та функціонування системи шкільної біологічної освіти в Україні впродовж XX - на початку XXI століть: I період (1901-1916 рр.) - становлення системи шкільної біологічної освіти за імперської доби; II період (1917-1920рр.) - педагогічні пошуки розбудови національної освіти в умовах відродження української державності; III період (1920-1991рр.) - становлення та розвиток радянської системи шкільної біологічної освіти, що містить п'ять етапів, та IV період (з 1991 року) - розвиток системи біологічної освіти в національній школі незалежної України.

Становлення учителя як необхідного елемента системи шкільної біологічної освіти має свою історію, що детерміноване чинниками суспільного середовища: соціально-політичними, економічними, культурологічними. На початку XX ст. багато педагогів усвідомлювали значення вчителя, його громадянської позиції у розбудові національної школи України. Так, вченийпедагог Михайло Іванович Демков (1859-1939) після здобуття 
ступеня кандидата природничих наук, працюючи в Глухівському учительському інституті, приділяв постійну увагу підготовці педагогічних кадрів. В учительській семінарії м. Прилуки Чернігівської області 31920 року М. Демков наголошував на необхідності систематичної самоосвіти педагогів. Його «Курс педагогіки для учительських інститутів, вищих жіночих курсів і педагогічних класів жіночих гімназій» (у двох частинах), що мав декілька перевидань, залишився одним 3 основних підручників для педагогічних інститутів до 1922 (Димков, 1910).

Від початку створення української школи (лютий 1917 р.) на Всеукраїнському учительському професійному з'їзді вироблено план національної освіти (серпень 1917 р.). У період перебудови шкільництва за прийнятим у Росії «Положенням про єдину трудову школу» (лютий-серпень 1919) не було жодної української школи 3 підготовки вчителів; переслідували працівників Академії наук (Ступарик, 1998:193].

Упродовж 1923-1925 pp. в Україні проведено масову перепідготовку вчителів у різних формах (місячних курсів за централізованим планом i програмою, районних виробничих конференцій перед початком навчального року тощо). Зокрема, 1925 року програма місячних курсів (173 години) містила три цикли: політичний (30 годин), загальний (36 годин), педагогічний (107 годин). Педагогічний цикл охоплював питання: сучасна наукова педагогіка, охорона дитинства, гігієна (по 10 годин); виробничі ухили в школі і форми їх проведення, дитячий рух, методика екскурсій (по 14 годин) та методика комплексної роботи в перші 4 роки у школі (35 годин). Значно посилилась участь вчителів у соціалістичному будівництві після Першого Всеукраїнського (м. Харків) і Всесоюзного вчительських з'їдів (м. Москва), що відбулись у січні 1925 року (Нова українська школа..., 1964:57).

У постанові ЦК ВКП(б) від 21 серпня 1932 року «Про навчальні програми i режим у початковій i середній школі» вказано про потребу використання досвідчених учителів для допомоги молодим кадрам. Районні методичні об'єднання охоплювали всіх учителів-біологів, проводили соціалістичні змагання. Співробітники інститутів (педагогічних, науково- 
дослідних) відвідували засідання методичного об'єднання вчителів і проводили для них консультації. У 30-х рр. ХХ століття підготовка «будівників комуністичного суспільства» викликала необхідність для вчительства проводити роботу над підвищенням «своєї загальної і соціальної педагогічної кваліфікації». Управління середньої школи Наркомосу пропонувало до вчительських січневих конференцій 1937 р. для обговорення проблеми антирелігійної роботи і використання навчальних посібників на уроках біології, повторення і закріплення знань з біології.

У зв'язку з розвитком справи кінофікації в 1938/39 н. р. перед учительством постали питання роботи 3 кінопосібником. На серпневих нарадах 1938 р. учителі, депутати Верховної Ради СРСР, їхали в райони для участі в конференціях, укладали угоди на соціалістичне змагання між міськими і сільськими школами. Для підняття якості комуністичного виховання вчителі вивчали «Короткий курс з історії ВКП (б)», рішення XVIII з’ізду.

Отже, будівництво нової школи передбачало діяльність вчителів передовсім як активних провідників ідей Комуністичної партії.

Для методичних об'єднань i предметних методичних комісій в 1940 році було рекомендовано таку тематику: вчення Лисенка i Мичуріна, антирелігійне виховання за викладанням біології, особливості методики ботаніки, зоології, анатомії і фізіології людини, основ дарвінізму тощо (Тематика для методичних об'єднань..., 1940).У розпорядженнях 1941 р. Наркомосом рекомендовано створення гуртків із вивчення техніки i сільськогосподарського виробництва при залученні до цього вчителів фізики та біології.

У повоєнний період майбутніх учителів біології орієнтували на теоретичні знання, менше уваги приділялося практиці (дослідництву на пришкільних ділянках, під час екскурсій), тому випускники не володіли достатніми знаннями про живу природу i сільське господарство. Покоління вчителів біології через відсутність навчального обладнання лабораторій і кабінетів, методичну непідготовленість, недооцінювання таких форм навчання біології, як лабораторні роботи, практичні заняття, екскурсії утримувалися від їх використання. 
Відповідно до Постанови РНК СРСР «Про поліпшення справи підготовки вчителів» (20 серпня 1945 р.) було заплановано ряд заходів: а) відмовитись від короткострокової підготовки вчителів 3 осіб без середньої освіти; б) відкрити педагогічні училища, педагогічні інститути 3 постійною кількістю набору студентів на I курс; в) розширити аспірантуру при педагогічних інститутах, запровадити річну підготовку до викладацької діяльності; г) звернутись по допомогу до місцевих рад депутатів трудящих для зміцнення навчально-матеріальної бази педагогічних інститутів і покращення обслуговування студентів (Ступарик, 1998). Для підготовки майбутніх учителів у навчальному плані XI педагогічного класу в тиждень виділялось 6 годин на педагогічну практику та 1 годину - на методику природознавства.

1957/1958 н. р. перед учителями біології стояли вимоги щодо розвитку і вдосконалення колективних форм роботи (методичні предметні комісії у школах, районі; кущові методоб'єднання); відвідування наукових і сільськогосподарських закладів, виставок; проведення конференцій, організація взаємного відвідування шкіл, допомога молодим учителям. Діяльність вчителів біології була спрямована на вивчення і використання рішень січневого Пленуму ЦК КПРС про розвиток сільського господарства (підготовка учнів до сільськогосподарської праці). У витягу 3 протоку засідання секретаріату ЦК ЛКСМУ від 4 лютого 1963 року «Про проведення комсомольського прийому молоді до педагогічних інститутів України в 1963 році» вказувалось, що для підготовки молоді до успішного складання вступних іспитів організовувались при всіх середніх школах і педагогічних інститутах підготовчі курси і консультаційні пункти (Про проведення комсомольського прийому..., 1963).

Перехід на загальну середню освіту розглянуто Всесоюзним з'їздом учителів (1968), де обговорено питання вдосконалення методики викладання, покращення підготовки майбутніх учителів, створення ефективної системи підвищення кваліфікації педагогів. Уведення вперше в 1968 році вступного іспиту з біології на деяких факультетах (відділеннях) ряду інститутів підвищило відповідальність педагогів за якість біологічної освіти. 
Унаслідок реорганізації навчально-виховного процесу педагогічних інститутів упродовж 1970-1980 pp. в Україні спостерігались позитивні наслідки: в 1979/1980 н. p. в загальноосвітніх школах працювало 452,2 тисячі вчителів. Значно зріс професійний рівень педагогів упродовж десяти років (19701980) - $з$ 61,1 відсотка до 77,3 (Народна освіта..., 1967:249).

Здобуття Україною незалежності зумовило становлення та розвиток національної освіти, зміни основних освітніх парадигм. Одним із завдань оновлення біологічної освіти в незалежній Україні виступає реформування загальноосвітньої школи - ii демократизація і гуманізація. Важливою ланкою у цьому процесі є підготовка i підвищення кваліфікації педагогічних кадрів на засадах цілеспрямованого посилення гуманістичного потенціалу кваліфікації вчителя.

Упродовж IV періоду розповсюджуються Всеукраїнські заходи: фахові конкурси «Учитель року» (з 1997 р.); II i III педагогічні конгреси з ухвалою завдань освітянської галузі (2005, 2009). Відбувся V Міжнародний фестиваль педагогічних інновацій та всеукраїнський семінар з методології реалізації перспективного педагогічного досвіду (2013). Проблеми вивчення, узагальнення i поширення досвіду творчих учителів стали одним із невідкладних завдань у розбудові національної школи Разом із тим виявляються суперечності: з одного боку, в педагогічній діяльності з'являється багато інноваційних підходів, формується прогресивний досвід роботи вчителів, а 3 іншого - ці надбання вкрай повільно реалізуються в навчально-виховному процесі. Тому виникає проблема в прискоренні процесу трансформації творчих здобутків у широку педагогічну практику, оперативного їх донесення до педагогічної громадськості.

\section{Висновки}

Прогресивні зміни в шкільній біологічній освіті можливі за умови глибокого розуміння кожним учителем іiі змісту, проблем, шляхів їхнього вирішення з метою переходу до нової якості шкільної біології. Аналіз діяльності освітніх установ дозволяє виділити пріоритетні тенденції розвитку вчителя в досліджуваний період. 
Революція 1917 р. сприяла становленню української школи, виробленню плану національної освіти, проте 1919 р. не створено жодної установи 3 підготовки вчителів. Згідно 3 постановою ЦК ВКП(б) «Про навчальні програми і режим у початковій i середній школі» (1932) набули поширення наставництво над молодими кадрами, соціалістичне змагання серед вчителів-біологів та антирелігійні заходи; відбувся I Український педагогічний конгрес (1935). Розвиток кінофікації в 1938/39 н. р. сприяв роботі учительства 3 кінопосібником; вчителі вивчали «Короткий курс 3 історії ВКП (б)», рішення XVIII з’їзду; відбулись перші науковопедагогічні конференції (1940). У повоєнний час проводили заходи на реалізацію Постанови РНК СРСР «Про поліпшення справи підготовки вчителів (1945р.). У підвищенні кваліфікації вчителів біології (1948-1958) застосовували мичуринську біологію, твори Т. Лисенка, К. Тимірязєва, В. Вільямса.

Протягом 1958-1970 рр. учителі проводили роз'яснювальну роботу щодо Директив XXIII з'їзду КПРС. Для вивчення у 1970/71 н. р. курсу загальної біології з IX класу Міністерством народної освіти республіки організовано для вчителів курси; для курсів підвищення кваліфікації вийшов збірник програм «Філософські проблеми природознавства» (1983). Реорганізація навчально-виховного процесу в педагогічних інститутах України (1980-1991) дала позитивні наслідки.

В умовах національного відродження виділяємо основні тенденції розвитку шкільної біологічної освіти, серед яких реформування формування творчої особистості вчителя як цільовий напрямок розвитку освіти, що набуває вирішального значення для розв'язання питань реалізації компетентнісного підходу в освіті, становлення в Україні громадянського суспільства, що забезпечить реалізацію завдань концепції Нової української школи.

Процес трансформації освіти потребує вдосконалення організаційно-методичної, інформаційно-наукової діяльності методичних служб через: поліпшення організаційного забезпечення процесу виявлення об'єктів досвіду; формування науковометодичної компетентності залучених до цієї роботи працівників 
та забезпечення керівництва цим процесом. Підготовка вчителя до педагогічної творчості як цілісна система будується на основі поєднання діалектичних категорій: загального (складова професійної загальнопедагогічної роботи вчителя); особливого (специфіка, яка зумовлена закономірностями творчого процесу i формуванням творчої особистості) та індивідуального (відображає залежність підготовки від особистісних якостей учителя). Якість, ефективність, вибір і рівний доступ до освіти як уніфіковані пріоритети української освітньої політики вимагають постійної уваги до системної підготовки вчителя 3 новими професійними якостями. Актуальною залишиться самоосвітня діяльність учителя як необхідний фактор розбудови української національної освіти.

\section{Література}

1. Демков М. Педагогика, eе современное положение и предстоящие задачи. Журнал Министерства народного просвещения. 1910. № 1. С. 81-102.

2. Кейран Л. Ф. Структура методики обучения как науки: на основе анализа методик обучения биологии. Москва : Педагогика, 1978. 168 с.

3. Любар О. О., Стельмахович М. Г., Федоренко Д. Т. Історія української педагогіки : навч. посіб. Київ : Знання, 2003. $450 \mathrm{c}$.

4. Народна освіта і педагогічна думка в Українській РСР (1917-1967). Київ : Рад. школа, 1967. 483 с.

5. Нова українська школа: Концептуальні засади реформування середньої школи (Ухвалена рішенням колегії $\mathrm{MOH}$ 27.10.2016 р.) / упоряд. : Л. Гриневич та iн. URL: http://mon.gov. ua $/ \%$ D0 $\% 9$ D $\%$ D0 $\%$ BE $\%$ D0 $\%$ B2 $\%$ D0 $\%$ B $8 \%$ D0 $\%$ BD $\%$ D0\%B $\% \% 20$ 2016/12/05/konczepcziya.pdf.

6. Про проведення комсомольського прийому молоді до педагогічних інститутів України в 1963 році: Витяг з протоку засідання секретаріату ЦК ЛКСМУ від 4 лютого 1963 року. Державний архів Львівської області. Ф. Р-163. Оп. 4. Спр. 939. Арк. 1-30.

7. Тематика для методичних об’єднань і предметних методичних комісій Інструкції і методичні вказівки за 1940 рік. 
Державний архів Львівської області. Ф. Р-163. Оп. 1. Од. зб. 139. Арк. 18-20.

8. Ступарик Б. М. Національна школа: витоки, становлення. Київ : ІЗМН, 1998. 334 с.

\section{Новикова Н. И.}

\section{Подготовка учителя как необходимое условие развития системы школьного биологического образования в Украине}

\section{Аннотация}

В статье рассмотрено школьное биологическое образование как целостная педагогическая система с определенной структурой. Проанализированы основные тенденции подготовки учителя как необходимого элемента системы школьного биологического образования, которое имеет свою историю, детерминированную социально-политическими, экономическими, культурологическими факторами общественной среды в соответствии с обозначенной периодизацией системы школьного биологического образования в Украине на протяжении XX - начала XXI веков. Определено, что гностически-профессиональный компонент предусматривает отбор и внедрение прогрессивного педагогического опыта как научнометодического условия функционирования системы. Определены направления повышения эффективности методической работы.

Ключевые слова: подготовка учителя, развитие, система школьного биологического образования, структура, тенденции.

\section{Новікова Н. І.}

\section{Підготовка вчителя як необхідна умова розвитку системи шкільної біологічної освіти в Україні}

\section{Анотація}

У статті розглянуто шкільну біологічну освіту як цілісну педагогічну систему 3 певною структурою. Проаналізовано 
основні тенденції підготовки вчителя як необхідного елемента системи шкільної біологічної освіти, що має свою історію, детерміновану соціально-політичними, економічними, культурологічними чинниками суспільного середовища відповідно до окресленої періодизації системи шкільної біологічної освіти в Україні впродовж XX - на початку XXI століть. Визначено, що гностично-професійний компонент передбачає відбір i впровадження прогресивного педагогічного досвіду як науковометодичної умови функціонування системи. Окреслено напрями підвищення ефективності методичної роботи.

Ключові слова: підготовка вчителя, розвиток, система шкільної біологічної освіти, структура, тенденції. 